\title{
Mengintegrasikan Life Skills ke Program Pelatihan Sepak Bola bagi Pengembangan Pemuda yang Positif
}

\author{
Integrating Life Skills into Soccer Training Programs for \\ Positive Youth Development
}

\author{
Herdy Sopyan Iqbal, Amung Ma'mun \& Nuryadi \\ Universitas Pendidikan Indonesia, Bandung, Jawa Barat, Indonesia \\ herdysofiq@upi.edu, amung@upi.edu,nuryadi_fpok@upi.edu
}

Naskah diterima tanggal 02/06/2019, direvisi akhir tanggal 24/06/2019, disetujui tanggal 11/12/2019

\begin{abstract}
Abstrak
Penelitian ini bertujuan untuk mengetahui pengaruh mengintegrasikan life skills ke dalam program pelatihan sepak bola untuk pengembangan remaja yang positif. Metode penelitian yang digunakan adalah eksperimen dengan model Quasi-Experimental Design. Teknik pengumpulan data yang digunakan dalam penelitian ini adalah kuesioner. Tehnik pengambilan sampel menggunakan purposive sampling. Jumlah sampel adalah 45 pemuda laki-laki berusia 15-20 tahun yang dibagi menjadi tiga kelompok, yaitu: Pelatihan sepak bola yang diberikan integrasi keterampilan hidup oleh 15 pemuda (kelompok a); Pelatihan sepak bola yang tidak diberikan integrasi life skills oleh 15 pemuda (kelompok b); dan kelompok yang tidak berpartisipasi dalam pelatihan olahraga oleh 15 pemuda (kelompok c). Hasil penelitian menunjukkan bahwa pengembangan life skills kelompok pelatihan sepak bola yang diberi integrasi life skills dalam program (kelompok a) lebih tinggi daripada kelompok pelatihan sepak bola yang tidak diberi integrasi life skills dalam program tersebut (kelompok b) dan kelompok yang tidak berpartisipasi dalam pelatihan olahraga (kelompok c). Pengembangan life skills remaja dapat diterapkan dalam kehidupan sehari-hari remaja sehingga mereka dapat digunakan untuk menghadapi kebutuhan dan tantangan hidup sesuai dengan manfaat life skills.
\end{abstract}

Kata Kunci: Life skills, Pelatihan Sepak Bola, Pengembangan Pemuda Positif

\begin{abstract}
This study aims to determine the effect of integrating life skills into a soccer training program for positive youth development. The research method used was experimental with the QuasiExperimental Design model. The data collection technique used in this study was questionnaires The sampling technique uses purposive sampling. The number of samples were 45 male youth aged 15-20 years which were divided into three groups, namely: Soccer training which was given the integration of life skills by 15 youths (group a); Soccer training that was not given life skills integration by 15 youths (group b); and group that did not participate in sports training by 15 youths (group A). The results showed that the development of the football training group life skills that were given the integration of life skills in the program (group a) was higher than the soccer training group that was not given the integration of life skills in the program (group $B$ ) and the group that did not participate in sports training (group C). The development of youth life skills can be implemented in the daily lives of youth so that they can be used to face the needs and challenges of life in accordance with the benefits of life skills.
\end{abstract}

Keywords: Life skills, Positive Youth Development, Soccer Training 


\section{PENDAHULUAN}

Saat ini pembahasan tentang life skills bagi pemuda menjadi aktual untuk dibahas karena berbagai alasan yang sangat rasional seperti masih angka putus sekolah dan angka pengangguran terbuka. Berdasarkan UU tentang Kepemudaan (2009) Pasal (1) ayat (1) bahwa Pemuda adalah warga negara Indonesia yang memasuki periode penting pertumbuhan dan perkembangan yang berusia 16 (enam belas) sampai 30 (tiga puluh) tahun. Menurut Pusat Data dan Statistik Pendidikan dan Kebudayaan (2017) mengungkapkan pemuda yang putus sekolah di Indonesia masih cukup tinggi walaupun mengalami penurunan dari tahun sebelumnya, untuk SMA berjumlah 31.123 pemuda dan SMK berjumlah 73.388 pemuda. Menurut data Badan Pusat Statistik tahun 2019 masih tingginya persentase pengangguran terbuka sebesar 5,01\% atau 6,82 juta jiwa dari jumlah penduduk angkatan kerja sebesar 136,18 juta jiwa. Pemuda di Indonesia telah menjadi salah satu perhatian utama negara sejak awal berdirinya negara hingga sekarang serta dianggap memainkan peran strategis dalam pembangunan nasional saat ini.

Penelitian survei menunjukkan bahwa banyak pemuda meninggalkan sekolah dan mulai mencari kerja sebelum mereka berniat memasuki lapangan kerja, sementara yang lainnya meninggalkan pendidikan menengah dan tinggi sebelum waktunya karena mereka tidak suka, atau merasa bahwa melanjutkan pendidikan mereka tidak akan banyak gunanya dalam mencari kerja (Sziraczki \& Reerink, 2004). Hal ini bisa dikarenakan perkembangan zaman dan teknologi yang semakin canggih di era Globalisasi. Era globalisasi yang tidak asing lagi di telinga masyarakat berakibat pada derasnya arus informasi dalam berbagai bidang kehidupan, tidak kenal batas-batas negara dan wilayah, sehingga berpengaruh terhadap seluruh aspek kehidupan. Mengantisipasi hal tersebut, maka menciptakan manusia yang unggul, merupakan satu tantangan dan keharusan menghadapi era globalisasi. Untuk mengantisipasi derasnya arus globalisasi ke arah yang negatif maka para pemuda harus di bekali dengan life skills atau keterampilan hidup yang positif.

Olahraga mampu memberikan dasar bagi pemuda untuk belajar tentang diri mereka sendiri dan memperoleh keterampilan yang akan terbukti bermanfaat di kemudian hari (Petitpas, Cornelius, Van Raalte, \& Jones, 2005). Pandangan ini dibagikan oleh orang lain yang berpendapat bahwa olahraga memiliki kapasitas untuk menantang dan memotivasi orang dengan cara yang tidak ditemukan dalam pengajaran kehidupan lainnya, seperti sekolah dan pekerjaan (Hansen, Larson, \& Dworkin, 2003). Sebagian besar penelitian hanya berfokus pada manfaat untuk kesehatan fisik saja. Namun, juga telah diakui bahwa olahraga mampu memberikan kontribusi bagi kesehatan masyarakat di luar fisik (Bingham, Parnell, Curran, Jones, \& Richardson, 2014; Curran, Bingham, Richardson, \& Parnell, 2014; Parnell \& Richardson, 2014; Parnell et al., 2015). Sebagai contoh, bukti ilmiah yang ada untuk membuat klaim bahwa hasil terkait dengan olahraga dan aktivitas fisik tidak terbatas hanya pada fisik saja, tetapi meluas ke dalam domain pembelajaran sosial, psikologis dan intelektual (Bailey, Hillman, Arent, \& Petitpas, 2016b, 2016a). Hasil non-fisik lebih lanjut dari partisipasi dalam olahraga dan aktivitas fisik adalah pengembangan life skills.

Beberapa dekade terakhir banyak minat pada praktisi akademisi dalam mempromosikan life skills yang dipandang sebagai bagian integral dari mempersiapkan pemuda dalam menghadapi tantangan kehidupan sehari-hari, dan memungkinkan partisipasi aktif dalam masyarakat. Danish \& Nellen (1997) mendefinisikan keterampilan hidup sebagai keterampilan yang memungkinkan individu untuk berhasil di lingkungan yang berbeda di mana mereka tinggal, seperti sekolah, rumah dan di lingkungan mereka. Para peneliti psikologi olahraga telah berupaya keras untuk lebih memahami bagaimana olahraga dapat disusun untuk mendorong pengembangan pemuda yang positif atau Positive Youth Development (PYD), kemudian olahraga 
juga telah diidentifikasi sebagai lingkungan yang menguntungkan untuk mempromosikan PYD, karena merupakan kegiatan di luar sekolah yang paling populer bagi pemuda (Fraser-Thomas, Côté, \& Deakin, 2005; Gould \& Carson, 2008; Guèvremont \& Findlay, 2002; Petitpas et al., 2005).

Menurut Walker et al (2005) dalam penelitiannya menyatakan bahwa gagasan struktur yang di sengaja mengacu pada kegiatan implementasi sengaja dalam lingkungan olahraga untuk mengajarkan life skills dan mengaplikasikannya di kehidupan nyata. Ada bukti studi mengenai program olahraga pemuda dapat mengembangkan life skills oleh Hardcastle et al., (2015) mengemukakan bahwa program tersebut cukup berhasil dalam mengembangkan perilaku dan motif adaptif termasuk keterlibatan yang lebih baik dalam pelatihan dan mengadopsi keterampilan manajemen dan perencanaan waktu dalam konteks di luar olahraga seperti pekerjaan rumah dan studi akademis. Penelitian terbaru yang dilakukan oleh Bean \& Forneris (2016) mengemukakan bahwa program olahraga secara terstruktur dirancang untuk mengajarkan life skills mungkin lebih cocok untuk mendorong hasil perkembangan anak muda positif, jika dibandingkan dengan program olahraga yang tidak sengaja dibuat.

Olahraga, khususnya sepak bola merupakan salah satu domain globalisasi yang paling dinamis, yang menerangi secara sosiologis, karena telah menjadi olahraga paling populer sejak abad ke-19 (Giulianotti \& Robertson, 2004). Mengingat peran global pada sepak bola, penting untuk mempertimbangkan perannya dalam mempromosikan dan mengembangkan life skills. Menurut data yang di keluarkan situs FIFA yang bertajuk 'Big Count' tahun 2006. FIFA berusaha mencatat seluruh pemain sepak bola yang ada di seluruh belahan dunia dari benua Amerika hingga Australia termasuk para pemain Indonesia. Jumlah pemain Indonesia yang dicatat oleh FIFA sebanyak 7.094.260 pemain, menjadikan Indonesia berada di peringkat ke-7 dunia. Sayangnya yang terdaftar di FIFA hanya
66.960 pemain dengan rincian pemain professional sebanyak 800 pemain, pemain futsal sebanyak 1000 pemain, pemain yunior U-18 sebanyak 62.600 pemain. Masih belum jelas, apakah sisanya yang belum terdaftar di PSSI itu pemain yang seperti apa atau memang belum terdaftar. Data itu di keluarkan 14 tahun yang lalu, mungkin saat ini bisa bertambah lagi dengan bangkitnya sepak bola wanita dan banyaknya sekolah sepak bola yang tersebar di seluruh penjuru Indonesia. Ini adalah kesempatan yang bagus untuk mempromosikan life skills ke dalam sepak bola. Ini adalah kesempatan yang bagus untuk mempromosikan life skills ke dalam sepak bola.

Peran pelatih menjadi penting untuk memastikan pengembangan olahraga pemuda melalui cara mereka menyusun lingkungan pelatihan dan perilaku yang mereka terapkan (Baker \& Horton, 2004; Côté \& Gilbert, 2009). Untuk mencapai pengembangan berbagai keterampilan, telah disarankan bahwa pelatih perlu menciptakan lingkungan yang berorientasi penguasaan, di mana penekanan ditempatkan pada peningkatan diri, bukan pada hasil akhir, atau lingkungan yang berpusat pada pelatih yang mengutamakan kemenangan dan keuntungan jangka pendek (Holt \& Neely, 2011). Jadi, untuk pelatih seharusnya mengadopsi lingkungan yang berorientasi penguasaan di mana mereka menghargai atlet sebagai orang yang memiliki kehidupan di luar olahraga.

Mengingat bukti dari Bean \& Forneris (2016), lebih lanjut Kendellen, Camiré, Bean, Forneris, \& Thompson (2016) menjelaskan ada empat prinsip untuk membantu para pelatih mengintegrasikan pengajaran life skills ke dalam olahraga, meskipun di rancangan untuk program golf di Kanada, tetapi praktisi cabang olahraga yang lain dapat menggunakan empat prinsip panduan ini ke dalam program latihan olahraga termasuk sepak bola: (a) fokus pada satu life skills per pelajaran, (b) memperkenalkan life skills pada awal pelajaran, (c) menerapkan strategi untuk mengajarkan life skills secara menyeluruh pelajaran, dan (d) tanyakan life skills pada akhir pelajaran. Prinsip ini 
harus di rancang dengan baik oleh pelatih dengan baik. agar pengembangan life skills dapat berjalan

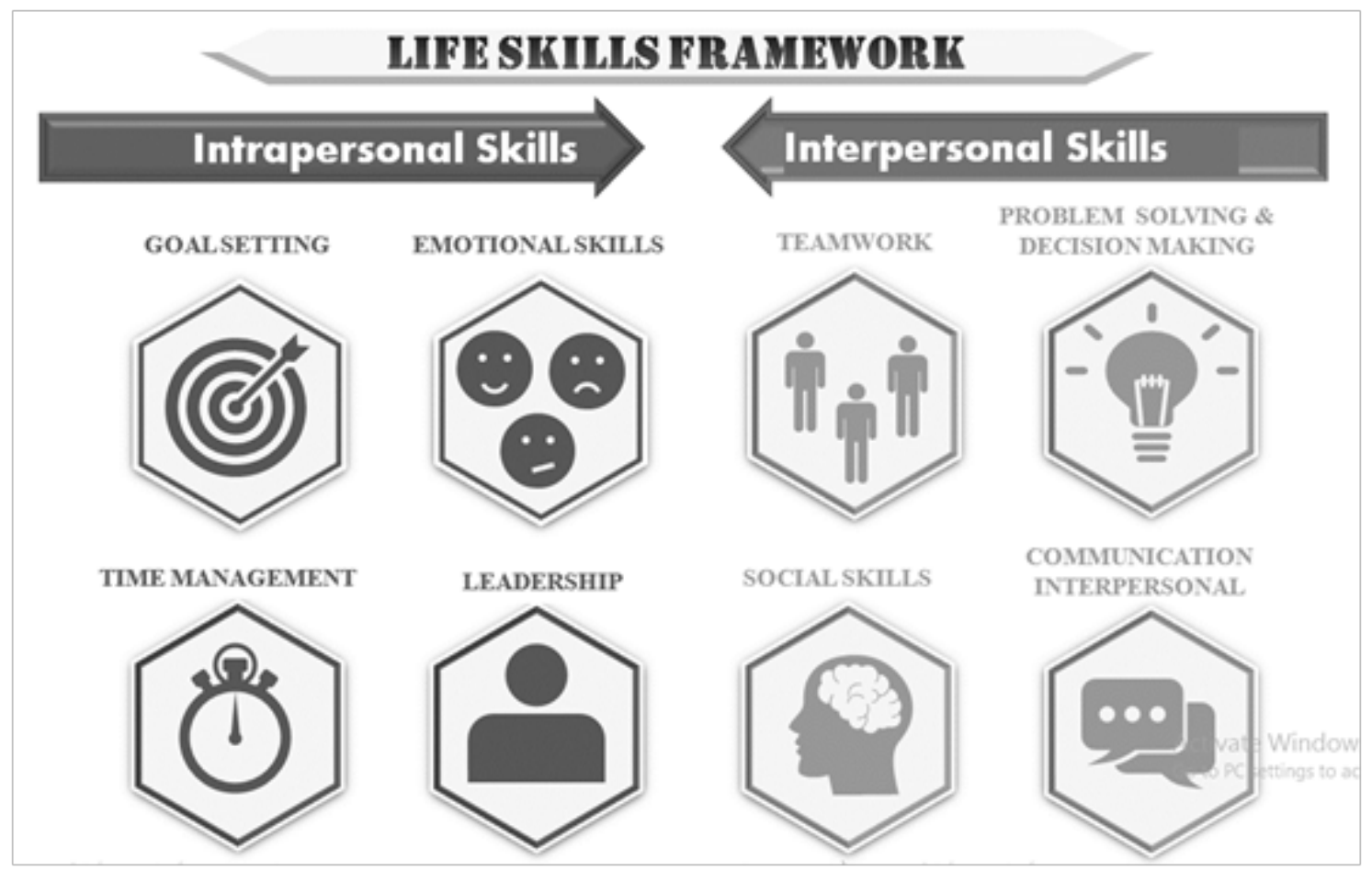

Gambar 1. Life skills framework untuk sekolah sepak bola

\section{Komponen Life Skills}

Kurikulum Filanesia

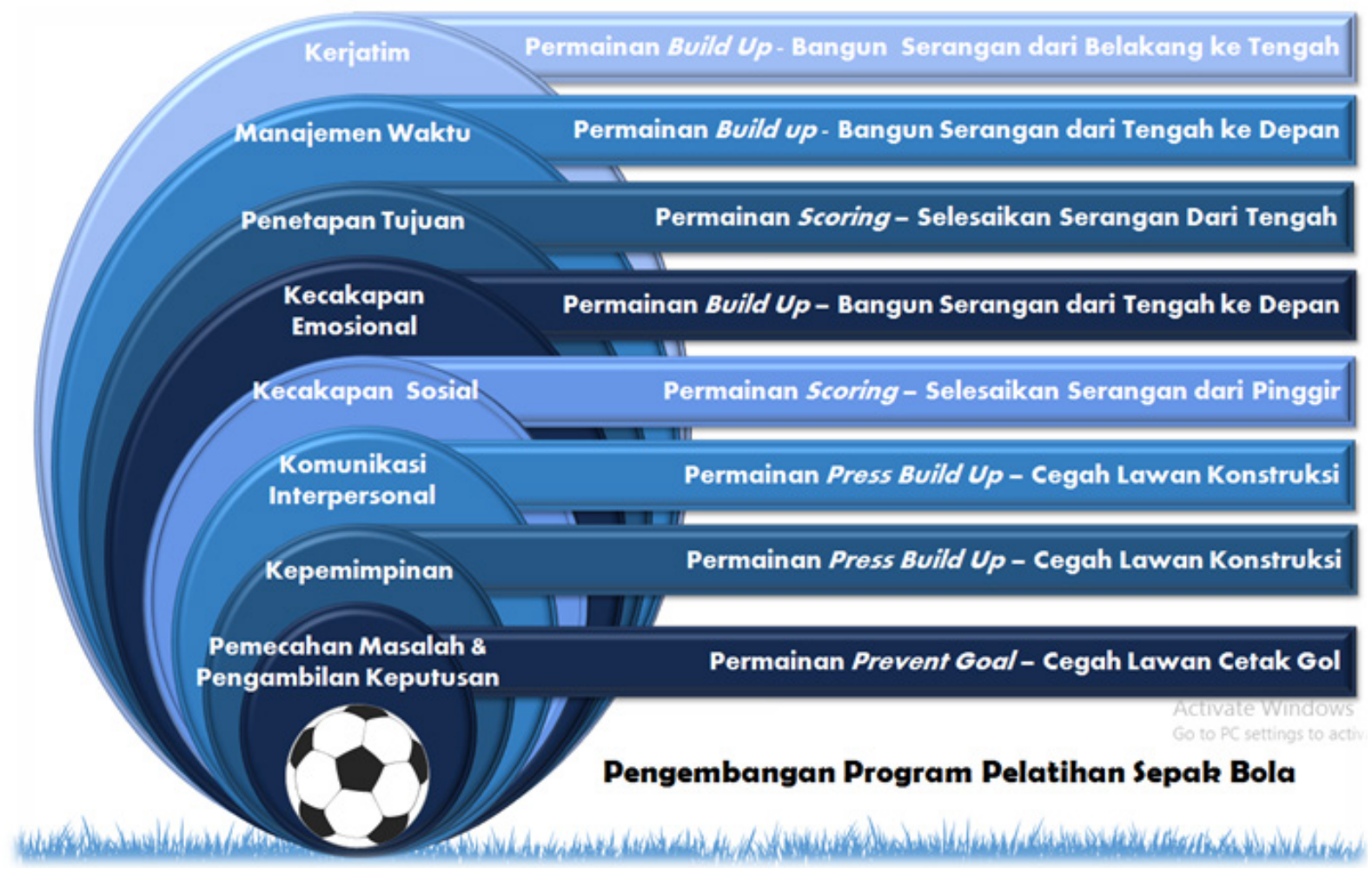

Gambar 2. Pengembangan program latihan sepak bola 
Sejumlah penelitian telah menunjukkan bahwa pemuda mengembangkan serangkaian kecakapan hidup melalui olahraga. (Rohmanasari, Ma'mun, \& Muhtar, 2018; Trottier \& Robitaille, 2014; Whitley, Wright, \& Gould, 2013). Sejalan dengan S. Danish, Forneris, Hodge, \& Heke (2004) kita melihat kecakapan hidup sebagai kompetensi perilaku, kognitif, interpersonal, dan intrapersonal yang dapat dipelajari, dikembangkan, dan disempurnakan. Dengan menggunakan Life skills Scale for Sport (LSSS), peneliti dapat menginvestigasi delapan life skills yang paling sering dikutip yang dimaksudkan oleh pemuda untuk dikembangkan melalui olahraga (Gambar 1) seperti timework, goal setting, time management, leadership, social skills, interpersonal communication, emotional skills, dan problem solving \& decision making (Cronin \& Allen, 2017). Skala ini memberikan peneliti dengan ukuran untuk menilai secara komprehensif delapan keterampilan hidup, dengan adanya skala ini memudahkan dalam mengukur pengembangan life skills dalam olahraga.

Mengutip framework (Gambar 1) dari Kendellen et al. (2016) bahwa kecakapan hidup diklasifikasikan sebagai intrapersonal skills (yaitu, keterampilan yang lebih bersifat internal, seperti penetapan tujuan) atau intrepersonal skills (yaitu, keterampilan yang berguna selama interaksi sosial, seperti kerjatim). Selanjutnya, setiap kecakapan hidup diberi ikon untuk secara visual mewakili kecakapan tersebut. Pada kesempatan kali ini program pelatihan akan menggunakan Kurikulum (FILANESIA) Filosofi Pembinaan Sepak Bola Indonesia (Danurwindo, Putera, \& Sidik, 2014) dengan mengintegrasikan life skills ke dalam program latihannya (Gambar 2). PSSI melalui High Performance Unit mewakili seluruh insan pelaku sepak bola Indonesia berusaha memotret kondisi sepak bola Indonesia, kemudian meriset kelebihan dan kelemahan sebagai titik awal untuk merumuskan suatu Filosofi Sepak bola Indonesia. Perumusan ini mempertimbangkan kelebihan-kelebihan pemain Indonesia, kultur-geografissosiologis masyarakat Indonesia dan tentunya tuntutan sepak bola top level dunia.

\section{METODE PENELITIAN}

Metode yang di gunakan dalam penelitian ini adalah dengan menggunakan metode penelitian Quasi-Experimental Design. Desain dalam penelitian ini adalah "The Matching-Only Pre-test-Post-test Control Group Design" (Fraenkel, Wallen, \& Hyun, 2012).

Tabel 1. Desain Penelitian

$\begin{array}{ccccc}\text { Grup A } & \mathrm{M} & 0_{1} & \mathrm{X} & 0_{2} \\ \text { Grup B } & \mathrm{M} & 0_{1} & \mathrm{C} & 0_{2} \\ \text { Grup C } & \mathrm{M} & 0_{1} & \mathrm{C} & 0_{2}\end{array}$

Keterangan pada tabel 1 yaitu kelompok A adalah kelompok pelatihan voli yang diberi integrasi life skills; Kelompok B adalah kelompok pelatihan sepak bola yang tidak diberi integrasi life skills; Kelompok $\mathrm{C}$ adalah kelompok yang tidak mengikuti pelatihan olahraga. $M$ merupakan subjek dalam setiap kelompok yang telah dicocokkan (pada variabel tertentu) tetapi tidak secara acak ditempatkan ke grup; $\mathrm{O} 1$ adalah pre-test; $\mathrm{O} 2$ adalah post-test; X merupakan perlakuan, dalam hal ini adalah program integrasi life skills ke dalam latihan olahraga dan $\mathrm{C}$ adalah kontrol atau pembanding.

Populasi pada penelitian ini adalah seluruh pemuda yang berusia 15-20 tahun di Kabupaten Karawang. Sampel pada penelitian ini adalah subkelompok dari populasi target, dengan demikian sampel pada penelitian ini adalah Kelompok A dan B masing-masing sebanyak 15 pemuda dari dua Sekolah Sepak Bola dan 15 pemuda dari Sekolah Menengah Atas. Teknik pengambilan sampel dilakukan secara purposive. Purposive sampling digunakan sebagai teknik penetuan sampel dengan beberapa pertimbangan tertentu, dengan kata lain berdasarkan pengetahuan sebelumnya dari populasi dan tujuan spesifik dari penelitian, peneliti menggunakan penilaian pribadi untuk memilih sampel.

Sebelum perlakuan di lakukan, semua pemuda melakukan pre-test pengisian angket Skala Kecakapan Hidup Bidang Olahraga yang sudah tersedia selama 45 menit. Setelah pre-test di lakukan kemudian pemuda mengikuti perlakuan sesuai dengan 
kelompoknya selama delapan pertemuan. Setelah perlakuan selesai di lakukan kemudian para pemuda melakukan posttest untuk menyelasikan pengisian kembali angket yang sudah tersedia selama 45 menit.

Pengembangan Life skills 47-item Life skills Scale for Sport (LSSS) digunakan untuk mengukur persepsi pengembangan life skills peserta melalui olahraga (Cronin \& Allen, 2017). Peserta diminta untuk 'menilai seberapa banyak olahraga telah mengajari Anda untuk melakukan keterampilan yang tercantum di bawah ini. Batang untuk setiap pertanyaan adalah 'Olahraga ini telah mengajarkan saya untuk ....' dan tanggapan diberikan pada 5- skala titik mulai dari 1 (Tidak sama sekali) hingga 5 (Sangat banyak). Contoh item termasuk: kerja tim (7 item), penetapan tujuan (7), manajemen waktu (4 item), keterampilan emosional (4 item), komunikasi antar-pribadi (4 item), keterampilan sosial (5 item), kepemimpinan (8 item), dan pemecahan masalah dan pengambilan keputusan (4 item). Penelitian sebelumnya memberikan bukti untuk validitas dan reliabilitas skala ini dengan peserta olahraga remaja (Cronin \& Allen, 2017). Dalam sampel saat ini, masingmasing subskala dari LSSS dan life skills total menampilkan reliabilitas konsistensi internal yang memadai dengan koefisien alpha mulai dari 0,81 hingga 0,96.

Pada analisis data, pengolahan data pada penelitian ini menggunakan cara kuantitatif dengan statistik deskriptif dan inferensial. Pengolahan data berupa tabulasi data menggunakan program Microsoft Excel 2013, kemudian untuk melakukan analisis data secara statistik deskriptif menggunakan bantuan software statistik yaitu IBM SPSS versi 23. Uji prasyarat statistik meliputi uji normalitas dan homogenitas menggunakan program SPSS versi 23. Uji hipotesis secara statistik menggunakan uji t yaitu Independent sample t-test.

\section{HASIL DAN PEMBAHASAN}

Adapun hipotesis pada penelitian dapat dirumuskan sebagai berikut: H0: Tidak ada perbedaan antara nilai rata-rata perkembangan life skills kelompok pelatihan sepak bola yang diberi integrasi life skills dengan nilai rata-rata kelompok pelatihan sepak bola yang tidak diberi integrasi life skills dan kelompok yang tidak mengikuti pelatihan olahraga. Ha: Terdapat perbedaan antara nilai rata-rata perkembangan life skills kelompok pelatihan sepak bola yang diberi integrasi life skills dengan nilai rata-rata kelompok pelatihan sepak bola yang tidak diberi integrasi life skills dan kelompok yang tidak mengikuti pelatihan olahraga.

\subsection{Hasil}

Tabel 2. Statistik deskriptif hasil penelitian

\begin{tabular}{ccccc}
\hline $\begin{array}{c}\text { Kelompok } \\
\text { Penelitian }\end{array}$ & N & $\begin{array}{c}\text { Pre- } \\
\text { test }\end{array}$ & $\begin{array}{c}\text { Post- } \\
\text { test }\end{array}$ & $\begin{array}{c}\text { Gain } \\
\text { Score }\end{array}$ \\
\hline A & 15 & 148,87 & 184,40 & 41,50 \\
\hline B & 15 & 161,60 & 173,27 & 16,58 \\
\hline C & 15 & 157,20 & 165,80 & 10,93 \\
\hline
\end{tabular}

Tabel 2 menyajikan jumlah nilai pretest, post-test dan nilai gain score ketiga kelompok. Kelompok A mendapat nilai gain score sebesar 41,50 \%, Kelompok B sebesar $16,58 \%$ dan kelompok $\mathrm{C}$ sebesar 10,93\%. Sedangkan untuk nilai pre-test dan posttest masing-masing kelompok mendapatkan jumlah kelompok A 148,87 dan 184,40; kelompok B 161,60 dan 173,27 dan kelompok C 157,20 dan 165,80. Perbedaan nilai gain score untuk menunjukkan bahwa kelompok A lebih baik perkembangan life skillsnya dari pada kelompok B dan kelompok C. Selanjutnya untuk lebih jelasnya bisa di lihat pada gambar 1 .

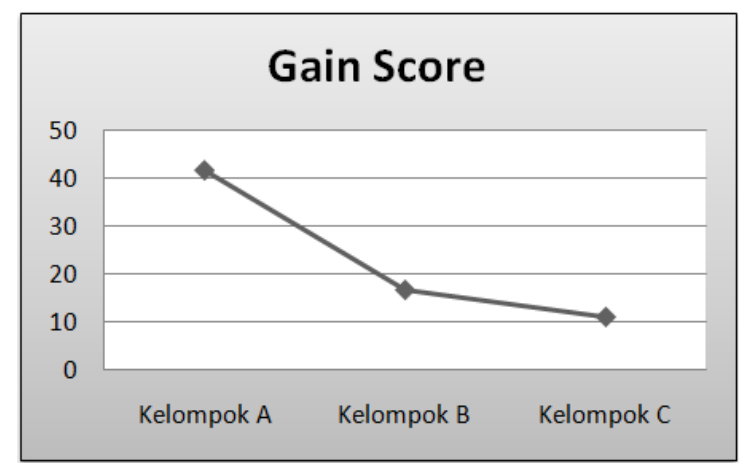

Diagram 1. Perbedaan nilai gain score semua kelompok

Setelah uji prasyarat dipenuhi maka uji hipotesis dapat dilakukan. Uji hipotesis pada penelitian ini menggunakan Uji 
hipotesis pada penelitian ini menggunakan uji ANOVA satu jalur yaitu One Way ANOVA menggunakan bantuan software IBM SPSS versi 23 for windows.

Tabel 3. Ringkasan hasil analisis one way annova

\begin{tabular}{lccccc}
\hline Sumber Variasi & Sum of Squares & df & Mean Square & F & Sig \\
\hline Between Groups & 7933,311 & 2 & 3966,655 & 35,385 &, 000 \\
\hline Within Groups & 4708,259 & 42 & 112,101 & & \\
\hline Total & 12641,570 & 44 & & & \\
\hline
\end{tabular}

Berdasarkan Tabel 3 dapat di ketahui bahwa nilai $\mathrm{F}$ hitung $=35,385$ dan signifikansi 0,000, dengan demikian jika $\mathrm{F}$ hitung di bandingkan dengan $\mathrm{F}$ tabel= 3,14. Di peroleh keputusan $F$ hitung $>F$ tabel sehingga Ho di tolak, yang berarti terdapat perbedaan. Kemudian di putuskan berdasarkan nilai signifikansi diperoleh bahwa nilai Sig. $(0,000)<0,05$ (tingkat signifikansi: $\alpha$ ) sehingga Ho di tolak. Telah di ketahui berdasarkan Tabel 3 bahwa terdapat perbedaan yang signifikan di antara ketiga kelompok penelitian. Selanjutnya untuk menjawab hipotesis ini dapat dilihat pada tabel 4 dengan menggunakan analisis post hoc test sebagai berikut:

Tabel 4. Ringkasan hasil post hoc test

\begin{tabular}{ccc}
\hline \multirow{2}{*}{ Kelompok Penelitian } & \multicolumn{2}{c}{ Tukey HSD } \\
\cline { 2 - 3 } & Perbedaan Nilai Rata-Rata & Sig. \\
\hline A-B & 24,91 & 0,000 \\
\hline A-C & 30,56 & 0,000 \\
\hline B-C & 5,64 & 0,320 \\
\hline
\end{tabular}

Diketahui pada data hasil uji TukeyHSD (Tabel 4) yang menguji perbedaan antara kelompok A dan kelompok B diperoleh perbedaan nilai rata-rata (Mean Difference) $=$ 24,91. Kemudian perbedaan antara kelompok A dan kelompok $\mathrm{C}$ diperoleh perbedaan nilai rata-rata (Mean Difference) $=30,56$. Selanjutnya berdasarkan data nilai signifikansi $=0,000$ diperoleh keputusan bahwa nilai sig. $<0,005$ (tingkat signifikansi; $\alpha$ ), sehingga diperoleh keputusan bahwa terdapat perbedaan nilai rata-rata kelompok A-B dan kelompok A-C adalah signifikan atau nyata. Telah di ketahui berdasarkan Tabel 2 kelompok penelitian A-B dan A-C terdapat perbedaan yang signifikan. Selanjutnya pada kelompok B-C diperoleh perbedaan nilai rata-rata (Main Difference $)=5,64$, kemudian berdasarkan bilai signifikansi $=0,000$ diperoleh keputusan bahwa nilai sig. $<0,005$ (tingkat signifikansi: $\alpha$ ), sehingga diperoleh keputusan bahwa tidak terdapat perbedaan nilai rata-rata kelompok B-C adalah tidak signifikan.

\subsection{Pembahasan}

Bersamaan dengan penelitian sebelumnya, penelitian ini membentuk argumen yang meyakinkan bahwa olahraga membantu kaum muda untuk mengembangkan keterampilan hidup mereka. Penelitian saat ini bertujuan untuk menilai perkembangan life skills antara kelompok pelatihan sepak bola yang di beri integrasi life skills (A) dengan kelompok pelatihan sepak bola tanpa integrasi life skills (B) dan kelompok yang tidak mengikuti pelatihan olahraga (C). Untuk mulai dengan, temuan mengungkapkan bahwa kelompok A lebih pesat perkembangan life skillsnya daripada kelompok B dan C. Secara khusus, temuan dari penelitian ini mengkonfirmasi hasil dari makalah ulasan 16 yang melaporkan bahwa orang muda merasa mereka mengembangkan keterampilan hidup berikut melalui olahraga: kerja tim, penetapan tujuan, manajemen waktu, keterampilan emosional, komunikasi interpersonal, keterampilan sosial, kepemimpinan, dan pemecahan masalah dan pengambilan keputusan. Ketika dibandingkan dengan penelitian dalam pendidikan jasmani (Johnston, Harwood, 
\& Minniti, 2013; Rohmanasari et al., 2018) tampaknya peserta olahraga pemuda memandang mereka mengembangkan delapan kecakapan hidup yang sama, tetapi pada tingkat yang lebih besar daripada siswa dalam kelas pendidikan jasmani. Mengingat banyaknya jumlah pemain sepak bola di Indonesia, jumlah pemain Indonesia yang dicatat oleh FIFA sebanyak 7.094.260 pemain, menjadikan Indonesia berada di peringkat ke-7 dunia. Sangat menggembirakan para pemain mengindikasikan bahwa mereka mengembangkan keterampilan hidup mereka melalui olahraga.

Dalam studi saat ini, menjanjikan bahwa LSSS (Cronin \& Allen, 2017) membuktikan ukuran yang dapat diandalkan dan valid untuk pengembangan kecakapan hidup. Hal ini terutama terjadi mengingat dominasi penelitian kualitatif dalam literatur dan kesulitan masa lalu dalam mengukur pengembangan kecakapan hidup dalam olahraga (Holt, Neely, Slater, Camiré, \& Côté, 2016). Temuan peneliti harus mendorong peneliti lain untuk memanfaatkan LSSS ketika menyelidiki pengembangan kecakapan hidup melalui olahraga. Pelatih atau praktisi olahraga yang memberikan program pengembangan remaja berbasis olahraga seperti program GOAL (S. J. Danish \& Nellen, 1997) dan kurikulum sepak bola FILANESIA (Danurwindo et al., 2014) juga dapat menggunakan LSSS untuk mengevaluasi hasil yang ditargetkan program mereka. Para peneliti dari olahraga dan psikologi perkembangan telah menyarankan bahwa semakin banyak keterampilan hidup yang dimiliki kaum muda, semakin besar kemungkinan mereka akan berkembang secara positif. Berdasarkan temuan-temuan baru ini, para peneliti dan praktisi harus memberi saran kepada para pelatih untuk membantu para peserta 'mengembangkan serangkaian kecakapan hidup melalui olahraga.

Pada dasarnya pelatih seharusnya menciptakan lingkungan belajar yang mendorong pengembangan life skills. Tetapi penelitian di Inggris Raya mengungkapkan bahwa pelatih sepak bola lebih banyak menggunakan gaya pelatihan otoriter (C. Cushion \& Jones, 2016; Partington, Cushion, \& Harvey, 2014; Potrac, Jones, \& Cushion, 2006). Dalam pelaksanaannya sedikit terjadi interaksi, umpan balik dan rendahnya tanya jawab. C. Cushion \& Jones (2016) mengemukakan bahwa pelatih mengadopsi pendekatan ini untuk melakukan kontrol dan disiplin terhadap pemain untuk mempertahankan status dalam sub-budaya sekolah sepak bola. Hal ini menghasilkan pemain menjadi pasif dan patuh dengan apa yang dikatakan oleh pelatih, bukan pembelajar aktif yang merasa dihargai (C. J. Cushion \& Jones, 2014; Denison, 2008). Sehubungan dengan ini, kecil kemungkinan bahwa lingkungan seperti ini akan memungkinkan pemain kesempatan untuk mengembangkan keterampilan hidup (Cope, Bailey, Parnell, \& Nicholls, 2016).

Ada beberapa saran bahwa tindakan dan perilaku pelatih adalah faktor mendasar terhadap pemain yang mengembangkan life skills. Pelatih perlu sengaja merencanakan program pelatihan jika ingin mengembangkan life skills, ada saran lebih lanjut bahwa hanya berlatih olahraga saja tidak akan menghasilkan pengembangan life skills yang positif (Fraser-Thomas et al., 2005). Alihalih, untuk pengembangan life skills yang ingin dicapai, dibutuhkan pertimbangan cermat dari para pelatih mengenai bagaimana mereka menyusun lingkungan belajar, berinteraksi dan membentuk hubungan dengan para pemain (Gould, Collins, Lauer, \& Chung, 2007). Lingkungan yang berorientasi penguasaan telah dilaporkan sebagai yang paling tepat dalam memberikan konteks di mana para pemain dapat mengembangkan berbagai keterampilan, termasuk life skills. Mengingat peran global pada sepak bola, penting untuk mempertimbangkan perannya dalam mempromosikan dan mengembangkan life skills.

Menurut literatur berbasis bukti yang ada (Bean \& Forneris, 2016) pelatih dapat memanfaatkan prinsip-prinsip pengajaran life skills berikut untuk mengembangkan keterampilan hidup peserta: menjadi disengaja, selektif, dan sistematis dalam 
mengajar keterampilan hidup; memberi peserta kesempatan untuk mengembangkan keterampilan hidup tertentu; menetapkan aturan untuk mengikuti dan meminta pertanggungjawaban peserta atas tindakan mereka; contohkan kecakapan hidup yang mereka ingin peserta pelajari; gunakan saatsaat yang dapat diajar untuk mengembangkan keterampilan hidup tertentu; membantu peserta untuk berpikir sendiri; dan melibatkan peserta dalam diskusi tim atau kelompok. Beberapa penelitian terbaru telah menguraikan bagaimana pelatih dilatih untuk mengintegrasikan keterampilan hidup ke dalam program pemuda Golf Kanada (Kendellen et al., 2016). Menurut Kendellen terdapat empat prinsip jika ingin mengajrkan life skills dengan program yang harus di rencanakan atau di sengaja; fokus pada satu life skills per pelajaran; memperkenalkan life skills pada awal pelajaran; menerapkan strategi untuk mengajarkan life skills secara menyeluruh pelajaran; tanyakan life skills pada akhir pelajaran. Prinsip ini harus di rancang dengan baik oleh pelatih agar pengembangan life skills dapat berjalan dengan baik.

Keterampilan mengelola emosi oleh pemuda dalam berolahraga sangat penting, terlebih pada olahraga yang bersifat kompetitif seperti sepak bola. Pernyataan tersebut didukung oleh Cope, Bailey, Parnell, \& Nicholls (2016) yang menyatakan bahwa sepak bola dan permainan tim kompetitif lainnya sebagai permainan yang baik untuk membangun karakter. Hal ini di karenakan pemuda yang mengikuti pelatihan sepak bola dengan integrasi life skills di dalam program terdapat integrasi dengan aspek-aspek pengembangan life skills, dengan di berikan integrasi life skills ke dalam program latihan sepak bola adalah programnya terdapat hubungan antara partisipasi olahraga dengan perkembangan life skills. Hasil ini sesuai dengna pernyataan oleh Camiré \& Kendellen (2016) bahwa olahraga dapat digunakan sebagai alat untuk meningkatkan life skills dan pengembangan pemuda yang positif. Sementara itu masuknya integrasi life skills dalam praktek olahraga dapat berfungsi sebagai effective model untuk belajar life skills (Papacharisis, Goudas, \& Danish, 2005).

Olahraga mampu memberikan dasar bagi pemuda untuk belajar tentang diri mereka sendiri dan memperoleh keterampilan yang akan terbukti bermanfaat di kemudian hari (Petitpas et al., 2005). Pandangan ini dibagikan oleh orang lain yang berpendapat bahwa olahraga memiliki kapasitas untuk menantang dan memotivasi orang dengan cara yang tidak ditemukan dalam pengajaran kehidupan lainnya, seperti sekolah dan pekerjaan (Hansen et al., 2003). Olahraga telah diusulkan sebagai lingkungan yang ideal untuk pengembangan life skills, karena olahraga salah satu kegiatan rekreasi yang paling populer untuk pemuda.

Di Indonesia sendiri sebetulnya sudah mempunyai Kurikulum Pembinaan Sepak Bola Indonesia atau lebih terkenal dengan sebutan FILANESIA. Kurikulum ini disusun oleh PSSI dan terbitkan tahun 2017 lalu, tetapi sayang kurikulum ini hanya membahasa bagaimana anak dan remaja terampil dalam hal keterampilan fisik, teknik dan taktik saja, kalau saja pembelajaran sosial salahsatunya life skills bisa juga di ajarkan ini akan menjadi luar biasa. Tentu saja untuk merubah kurikulum atau membuat ulang lagi harus ada kepedulian dari semua insan terkait dan dukungan dari pemerintah dalam hal ini Kemenpora karena menurut Ma'mun (2019) menyatakan penilaian fakta historis yang relevan menunjukkan bahwa pemerintah memainkan peran abadi dan strategis dalam pengembangan kebijakan olahraga. Jadi keinginan kurikulum FILANESIA terintegrasi life skills harus ada dukungan dari pemerintah sebagai pemangku kebijakan dan membahasanya lebih dalam.

Mengingat bahwa program integrasi life skills ke dalam pelatihan olahraga hanya delapan sesi 90 menit, hasilnya cukup efektif untuk mengembangkan life skills pemuda dan ini sesuai dengan temuan dari implementasi program 'GOAL' dilingkungan sekolah (S. J. Danish \& Nellen, 1997), karena program 'GOAL' dilaksanakan dengan waktu 10 jam, 10 sesi. Dengan berkembangnya life 
skills seperti kerja tim, penetapan tujuan, manajemen waktu, kecakapan emosional, komunikasi interpersonal, kecakapan sosial, kepemimpinan, pemecahan masalah dan pengambilan keputusan, pemuda memiliki kesempatan yang baik untuk menjadi individu yang lebih baik, atlet yang lebih baik dari sikap maupun keterampilan bermainnya, dan anggota masyarakat yang lebih peduli dan produktif.

\section{KESIMPULAN}

Singkatnya, penelitian ini menemukan bahwa peserta olahraga pemuda merasa mereka sedang mengembangkan keterampilan hidup berikut melalui olahraga: kerja tim, penetapan tujuan, manajemen waktu, keterampilan emosional, komunikasi antarpribadi, keterampilan sosial, kepemimpinan, dan pemecahan masalah dan keputusan membuat. Temuan menunjukkan bahwa bahwa kelompok pelatihan sepak bola yang diberi integrasi life skills lebih pesat perkembangan life skillsnya daripada kelompok pelatihan sepak bola tanpa integrasi life skills dan kelompok yang tidak mengikuti pelatihan olahraga. Secara umum, temuan ini mendukung prinsip- prinsip pengajaran life skills (Kendellen et al., 2016), program-program yang terstruktur secara sengaja (Bean \& Forneris, 2016) dan pengembangan life skills (Cronin \& Allen, 2017) yang seharusnya mendorong penelitian di masa depan untuk menggunakan kerangka kerja ini ketika menyelidiki pengembangan kaum muda melalui olahraga.

Dalam praktiknya, hasilnya menunjukkan bahwa pelatih harus bekerja untuk memastikan pemuda mengembangkan berbagai kecakapan hidup melalui partisipasi mereka dalam olahraga. Oleh karena itu, dapat disimpulkan bahwa perkembangan life skills pemuda yang mengikuti pelatihan sepak bola yang di beri integrasi life skills lebih baik jika di bandingkan dengan perkembangan life skills pemuda yang mengikuti pelatihan sepak bola tanpa di beri integrasi life skills ke dalam programnya. Perkembangan life skills ini dapat di implemetasikan didalam kehidupan sehari-hari, sehingga dapat di gunakan untuk menghadapi tuntutan dan tantangan di masa depan secara efektif. Hasil ini didapatkan setelah melakukan delapan kali pertemuan, hasil yang sangat baik apalagi jika program ini dilakukan secara berkelanjutan, bukan tidak mungkin hasilnya akan lebih baik lagi.

\section{DAFTAR PUSTAKA}

Bailey, R., Hillman, C., Arent, S., \& Petitpas, A. (2016a). Physical Activity: An Underestimated Investment in Human Capital? Journal of Physical Activity and Health, 10(3), 289-308. https://doi.org/10.1123/ jpah.10.3.289

Bailey, R., Hillman, C., Arent, S., \& Petitpas, A. (2016b). Physical Activity as an Investment in Personal and Social Change: The Human Capital Model. Journal of Physical Activity and Health, 9(8), 1053-1055. https:// doi.org/10.1123/jpah.9.8.1053

Baker, J., \& Horton, S. (2004). A review of primary and secondary influences on sport expertise A review of primary and secondary. (April 2013), 37-41. https://doi.org/10.1080/1359813042000314781

Bean, C., \& Forneris, T. (2016). Examining the Importance of Intentionally Structuring the Youth Sport Context to Facilitate Positive Youth Development. Journal of Applied Sport Psychology, 28(4), 410-425. https://doi. org/10.1080/10413200.2016.1164764

Bingham, D. D., Parnell, D., Curran, K., Jones, R., \& Richardson, D. (2014). Fit Fans: perspectives of a practitioner and understanding participant health needs within a health promotion programme for older men delivered within an English Premier League Football Club. Soccer and Society, 15(6), 883-901. https://doi.org/10. 1080/14660970.2014.920624

Camiré, M., \& Kendellen, K. (2016). Coaching for Positive Youth Development in High School Sport. In Positive Youth Development Through Sport (pp. 126-136). https://doi.org/10.4324/9781315709499-11

Cope, E., Bailey, R., Parnell, D., \& Nicholls, A. (2016). Football, sport and the development of young people's life skills. Sport in Society, 20(7), 789-801. https://doi.org/10.1080/17430437.2016.1207771

Côté, J., \& Gilbert, W. (2009). An Integrative Definition of Coaching Effectiveness and Expertise. (September 2009). https://doi.org/10.1260/174795409789623892 
Cronin, L. D., \& Allen, J. (2017). Development and initial validation of the Life Skills Scale for Sport. Psychology of Sport and Exercise, 28, 105-119. https://doi.org/10.1016/j.psychsport.2016.11.001

Curran, K., Bingham, D. D., Richardson, D., \& Parnell, D. (2014). Ethnographic engagement from within a Football in the Community programme at an English Premier League football club. Soccer and Society, 15(6), 934-950. https://doi.org/10.1080/14660970.2014.920627

Cushion, C. J., \& Jones, R. L. (2014). A Bourdieusian analysis of cultural reproduction: socialisation and the "hidden curriculum" in professional football. Sport, Education and Society, 19(3), 276-298. https://doi. org/10.1080/13573322.2012.666966

Cushion, C., \& Jones, R. L. (2016). Power, Discourse, and Symbolic Violence in Professional Youth Soccer: The Case of Albion Football Club. Sociology of Sport Journal, 23(2), 142-161. https://doi.org/10.1123/ ssj.23.2.142

Danish, S., Forneris, T., Hodge, K., \& Heke, I. (2004). Enhancing Youth Development Through Sport. World Leisure Journal, 46(3), 38-49. https://doi.org/10.1080/04419057.2004.9674365

Danish, S. J., \& Nellen, V. C. (1997). New roles for sport psychologists: Teaching life skills through sport to at-risk youth. Quest, 49(1), 100-113. https://doi.org/10.1080/00336297.1997.10484226

Danurwindo, Putera, G., \& Sidik, B. (2014). Kurikulum Pembinaan Sepakbola Indonesia. 180.

Denison,J.(2008). SocialTheory forCoaches:AFoucauldianReading ofOneAthlete'sPoorPerformance.International Journal of Sports Science \& Coaching, 2(4), 369-383. https://doi.org/10.1260/174795407783359777

Fraenkel, J. R., Wallen, N. E., \& Hyun, H. H. (2012). How to Design and Evaluate Research in Education. In The McGraw-Hill Companies (Eighth Edi, Vol. 53). https://doi.org/10.1017/CBO9781107415324.004

Fraser-Thomas, J. L., Côté, J., \& Deakin, J. (2005). Youth sport programs: an avenue to foster positive youth development. Physical Education \& Sport Pedagogy, 10(1), 19-40. https://doi. org/10.1080/1740898042000334890

Giulianotti, R., \& Robertson, R. (2004). The globalization of football : a study in the glocalization of the 'serious life .' 55(4). https://doi.org/10.1111/j.1468-4446.2004.00037.x

Gould,D., \& Carson, S.(2008). Lifeskills development through sport: currentstatus and future directions. International Review of Sport and Exercise Psychology, 1(1), 58-78. https://doi.org/10.1080/17509840701834573

Gould, D., Collins, K., Lauer, L., \& Chung, Y. (2007). Coaching life skills through football: A study of award winning high school coaches. Journal of Applied Sport Psychology, 19(1), 16-37. https://doi. org/10.1080/10413200601113786

Guèvremont, A., \& Findlay, L. C. (2002). Organized extracurricular activities of Canadian children and youth. Health Reports- Statistics Canada, 19, Catalogue no. 82-003-XPE. (May 2014).

Hansen, D. M., Larson, R. W., \& Dworkin, J. B. (2003). What adolescents learn in organized youth activities. Journal of Research on Adolescence, 13(1), 25-55.

Hardcastle, S. J., Hancox, J., Hattar, A., Maxwell-Smith, C., Thøgersen-Ntoumani, C., \& Hagger, M. S. (2015). Motivating the unmotivated: how can health behavior be changed in those unwilling to change? Frontiers in Psychology, 6(1), 835. https://doi.org/10.3389/fpsyg.2015.00835

Holt, N. L., \& Neely, K. C. (2011). Positive Youth Development Through Sport. Positive Youth Development Through Sport, (April), 21-33. https://doi.org/10.4324/9781315709499-3

Holt, N. L., Neely, K. C., Slater, L. G., Camiré, M., \& Côté, J. (2016). A grounded theory of positive youth development through sport based on results from a qualitative meta-study. 10(1), 1-49.

Johnston, J., Harwood, C., \& Minniti, A. M. (2013). Positive Youth Development in Swimming: Clarification and Consensus of Key Psychosocial Assets. Journal of Applied Sport Psychology, 25(4), 392-411. https://doi. org/10.1080/10413200.2012.747571

Kendellen, K., Camiré, M., Bean, C., Forneris, T., \& Thompson, J. (2016). Integrating life skills into Golf Canada's youth programs: Insights into a successful research to practice partnership. Journal of Sport Psychology in Action, 8(1), 34-46. https://doi.org/10.1080/21520704.2016.1205699

Papacharisis, V., Goudas, M., \& Danish, S. J. (2005). Journal of Applied Sport Psychology The Effectiveness of Teaching a Life Skills Program in a Sport Context. (April 2015), 37-41. https://doi. org/10.1080/10413200591010139

Parnell, D., \& Richardson, D. (2014). Introduction. Soccer and Society, 15(6), 823-827. https://doi.org/10.1080/ 14660970.2014.920619

Parnell, D., Rutherford, Z., Zwolinsky, S., Hargreaves, J., Rigby, M., Pringle, A., ... Trotter, L. (2015). Reaching 
older people with PA delivered in football clubs: the reach, adoption and implementation characteristics of the Extra Time Programme. BMC Public Health, 15(1). https://doi.org/10.1186/s12889-015-1560-5

Partington, M., Cushion, C., \& Harvey, S. (2014). An investigation of the effect of athletes' age on the coaching behaviours of professional top-level youth soccer coaches. Journal of Sports Sciences, 32(5), 403-414. https://doi.org/10.1080/02640414.2013.835063

Petitpas, A. J., Cornelius, A. E., Van Raalte, J. L., \& Jones, T. (2005). A Framework for Planning Youth Sport Programs That Foster Psychosocial Development. The Sport Psychologist, 19(1), 63-80. https://doi. org/10.1123/tsp.19.1.63

Potrac, P., Jones, R., \& Cushion, C. (2006). Understanding Power and the Coach's Role in Professional English Soccer: A Preliminary Investigation of Coach Behaviour. Soccer \& Society, 8(1), 33-49. https://doi. org/10.1080/14660970600989509

Rohmanasari, R., Ma’mun, A., \& Muhtar, T. (2018). Dampak Kegiatan Ekstrakurikuler terhadap Perkembangan Life Skills Siswa Sekolah Menengah Atas. 371-382.

Sziraczki, G., \& Reerink, A. (2004). Report of Survey on the School-to-Work Transition in Indonesia. (14), 67.

Trottier, C., \& Robitaille, S. (2014). Fostering Life Skills Development in High School and Community Sport : A Comparative Analysis of the Coach 's Role. (2000), 10-21.

Whitley, M. A., Wright, E. M., \& Gould, D. (2013). Journal of Sport for Development Coaches'Perspectives on Sport-Plus Programmes for Underserved Youth: An Exploratory Study in South Africa. 1(2). 